\title{
Not So Universal After All: Exploring the Meaning and Use of Government Transparency in Consensual and Majoritarian Democracies
}

\section{Stephan Grimmelikhuijsen \& Jyldyz Kasymova}

To cite this article: Stephan Grimmelikhuijsen \& Jyldyz Kasymova (2015) Not So Universal After All: Exploring the Meaning and Use of Government Transparency in Consensual and Majoritarian Democracies, Public Integrity, 17:4, 389-407, DOI: 10.1080/10999922.2015.1077040

To link to this article: http://dx.doi.org/10.1080/10999922.2015.1077040

Published online: 11 Sep 2015.

Submit your article to this journal $\sqsubset$

Џll Article views: 132

Q View related articles $\square$

View Crossmark data ¿ 


\title{
Not So Universal After All: Exploring the Meaning and Use of Government Transparency in Consensual and Majoritarian Democracies
}

\author{
Stephan Grimmelikhuijsen \\ Utrecht University \\ Jyldyz Kasymova \\ Buffalo State (SUNY)
}

\begin{abstract}
Government transparency has become a widespread value of democratic governance, yet theory suggests that various forces shape transparency differently in consensual and majoritarian regimes. As a result, transparency may achieve different goals in different democratic regimes. Presented here are the results of a study comparing the Netherlands and New Jersey. Results reveal that ideas about information disclosure in the two jurisdictions are distinctly different. They suggest that in a majoritarian democracy transparency is needed to empower interests that are not represented in the decision-making process, whereas in a consensual democracy a wider range of interests is already represented in decision-making, and thus there is less need for transparency as a means to empower citizens. This implies that despite its universal application, there is no "one size fits all" solution for government transparency.
\end{abstract}

Government transparency is seen as an important democratic value by many and is widely thought to enable government accountability and undergird trust (Grimmelikhuijsen \& Meijer, 2014; Licht, Naurin, Esaiasson, \& Gilljam, 2013; Van Zyl, 2014). In fact, it seems as if transparency has attained quasi-religious status and has found resonance in many countries around the globe (Hood, 2006; Relly \& Sabharwal, 2009). As a result, many scholars have sought to ascertain what factors drive government transparency at the international, national, or local level (Cucciniello \& Nasi, 2014; Grimmelikhuijsen \& Welch, 2012; Piotrowski, 2011; Relly \& Sabharwal, 2009; Royo, Yetano, \& Acerete, 2014; Tan, 2014; Welch \& Wong, 2001). Their studies have provided valuable insights on the specific variables that positively affect government transparency, such as media attention (Grimmelikhuijsen \& Welch, 2012) and NGO involvement (Tan, 2014).

Although scholars have shown that there is a statistical correlation between the existence of democracy and transparency (Relly \& Sabharwal, 2009), current research has overlooked the fact that government transparency, despite its universal application and the importance attached to it, may mean different things in different countries. One crucial but neglected variable that shapes the driving forces behind transparency is the type of democratic environment

Correspondence should be sent to Stephan Grimmelikhuijsen, School of Governance, Utrecht University, Bijlhouwerstraat 6, Utrecht, 3511 ZC, the Netherlands. E-mail: s.g.grimmelikhuijsen@uu.nl 
characterizing a government organization. This is highly relevant because it has been established that forces like the media, industry, interest groups, and intragovernmental relations in majoritarian democracies differ significantly from their counterparts in consensual democracies (Hallin \& Mancini, 2004; Lijphart, 1999; Lijphart \& Crepaz, 1991), and this in turn affects how transparency is perceived and used. Hitherto, the influence of the type of democratic regime on how transparency is perceived and used has not been investigated. To study this question, the focus is on perceptions of transparency held by administrators and stakeholders in local government. Although perceptions of transparency and actual transparency may differ, perceptions are highly relevant because, as stated in the Thomas theorem, "If men [sic] define situations as real, they are real in their consequences" (Thomas, 1928, p. 572). In addition, the different meanings attached to transparency may result in different applications.

The present study has two specific features in that it focuses on a particular policy context for transparency in a specifically democratic context. The policy context is proactive information disclosure of air pollution information by local government. The first reason to focus on this context is that air pollution is a very salient and contested topic. The OECD has reported that air pollution is a widespread problem in numerous cities worldwide (Organisation for Economic Co-operation and Development, 2013). Furthermore, the European Union enforces a set of directives dictating that air pollution should be reduced in European cities. In other parts of the world, air pollution also affects public health. One of the most notorious examples is the heavy smog affecting citizens in Beijing every day.

Transparency plays a key role in combating air pollution. The idea is that if the severity of air pollution is disclosed, (1) citizens will make different individual choices-for instance, by not using their cars or not going outside when there is severe smog; and (2) citizens may pressure their government to take policy measures to make the air cleaner. For instance, the Beijing government now uses proactive transparency to warn citizens and to encourage cities and companies to limit pollution (Beam, 2015; Tan, 2014); online and up-to-date information warns citizens about current smog updates. In the United States, the Toxic Release Inventory shows industrial emissions nationwide and has led to notable reductions (Beierle, 2004). Overall, air pollution is a salient policy area in which transparency plays an important role. Therefore, it is important to know how a democratic environment affects transparency perceptions and applications.

The democratic context consists of two very different local democratic environments. Based on Lijphart's classification framework for types of democracies (1999), we compare a jurisdiction in a typical majoritarian context to a jurisdiction in a typical consensual context. Majoritarian versus consensual is considered a major dividing line to describe how a democracy works (Lijphart, 1999), and in turn it influences several key variables of transparency, such as the role of pressure groups (Grimmelikhuijsen \& Welch, 2012; Lijphart \& Crepaz, 1991), the media (Cho, Chen, \& Roberts, 2008; Hallin \& Mancini, 2004), intragovernmental relations (Tan, 2014), and relations with industrial companies (Beierle, 2004; Relly \& Sabharwal, 2009). This leads to the following central question:

How are perceptions and use of environmental transparency shaped in a majoritarian democratic context and in a consensual democratic context?

This question is examined in the context of environmental transparency in New Jersey, a state of the United States, a typical majoritarian democracy, and in the Netherlands, a typical 
consensual democracy. The rich, in-depth research data employed here, compiled from interviews and document analyses, link the democratic context with known transparency determinants and proactive information disclosure in the Netherlands and in New Jersey. Comparing a U.S. state to a country is thought to be a more proper comparison than a U.S.-wide comparison because of the strong and nationlike capacities that American states possess and the similarities between New Jersey and the Netherlands in terms of size and population. The article concludes with some theoretical propositions that may be tested in future research.

\section{UNDERLYING MECHANISMS AFFECTING TRANSPARENCY AND TYPE OF DEMOCRACY}

Although government transparency has found near-universal application, little attention has been paid to how the democratic context of a country shapes how transparency is perceived and implemented. Transparency is part of the democratic context, but at the same time it shapes this context and is shaped by it (cf. Meijer, 2013). This means that different types of democracies attach very different meanings and possibly uses to government transparency, affecting its goals and how it is used by administrators and citizens. The type of democracy is an important variable in understanding how transparency perceptions and uses are shaped.

In 1947, Dahl was one of the first to note that democracies around the globe are not all the same, and thus, although they share some key components, that each democracy has its own very distinctive characteristics based on historical, social, and cultural developments. He highlighted that "a particular nation-state embodies the results of many historical episodes, traumas, failures, and successes which have in turn created peculiar habits, mores, institutionalized patterns of behaviour" (Dahl, 1947, p. 8).

Lijphart built on Dahl's idea and developed a classification of democracies based on the institutional differences between countries. In Patterns of Democracy, Lijphart classifies democracies into two main categories: majoritarian and consensual. The majoritarian system creates a political terrain that is diverse and competitive, in which "majorities should govern" and "minorities should oppose" (Lijphart, 1999, p. 31). Lijphart (1999, p. 16) further argues that the majoritarian model of democracy creates a competitive and adversarial pattern of government vs. opposition and a system of "free-for-all pluralism." Cabinets in the majoritarian model tend to have concentrated power, whereas the consensus model inhibits power sharing between majority and opposition. According to Lijphart's classification, the Netherlands can be characterized as a typical consensual democracy, while the United States fits the model of a typical majoritarian democracy.

The type of democracy has several implications for some of the key stakeholders in the power struggle that shapes transparency (Larsen \& Walby, 2013; Meijer, 2013; Roberts, 2005; Van Zyl, 2014). Influential stakeholders that have been identified in prior research include the news media, industry/business, civil society/nonprofits, and intrastate relations (Grimmelikhuijsen \& Welch, 2012; Meijer, 2013; Relly \& Sabharwal, 2009; Tan, 2014). The roles of these stakeholders are discussed below, along with how they are affected by the type of democratic environment.

First, the role of the media is often portrayed as that of a watchdog. As such, active local media may increase environmental transparency (see Cho et al., 2008). Indeed, there is some 
evidence that numerous governments have implemented information-access laws to ensure media access to information or to expose health and environmental issues (see Oswald, 1994, p. 412; Relly \& Sabharwal, 2009, p. 149). However, the more aggressive media culture in the United States, as compared to the Netherlands (e.g., Hallin \& Mancini, 2004), is likely to influence how administrators perceive and act on environmental transparency. The presence of more aggressive media may lead local governments to be less forthcoming in providing information in order to prevent the loss of reputation and control. In a majoritarian culture such as the United States, the more aversive and polarized media climate affects how forthcoming public officials will be in processing air pollution information.

The second key stakeholder is industry and/or business (see also Grimmelikhuijsen \& Welch, 2012). Industry may seek to limit government transparency because information disclosure could provide advantages to competitors or lead to increased regulatory pressure. The Toxic Release Inventory (TRI) in the United States is a well-known example in the field of environmental transparency. In this case, public disclosure of data on releases of toxic chemicals and compounds has resulted in behavioral changes by pollution-emitting firms (Beierle, 2004). Again, there is a difference between majoritarian and consensual democracies. In the stakeholder culture that characterizes consensual democracies such as the Netherlands, companies are generally more concerned about corporate responsibility, which reportedly leads to better reporting and transparent information sharing. A shareholder culture, as found in the United States, focuses on maximizing shareholders' interests and thus is reportedly less forthcoming in disclosing information because that may harm corporate interests (Alrazi et al., 2010).

The institutional role of interest groups varies too. Consensus democracies tend to be more corporatist, while majoritarian systems exhibit pluralism (Lijphart, 1999; Lijphart \& Crepaz, 1991). In a corporatist environment, relations among business, pressure groups, and the state tend to be less antagonistic and more focused on finding consensus. The Netherlands has a long history of corporatist political decision-making, whereas the United States is a well-known example of a country where a broad range of lobbying groups exert pressure in order to change policies or regulations (e.g., Furlong, 1997; Grossmann, 2012). This extends to environmental policymaking, where group influence is recognized to be a strong determinant of environmental regulations and policies (Binder \& Neumayer, 2005; Ringquist, 1993, p. 112).

This has several implications. The most important is that the majoritarian model favors well-organized groups, which may work to a disadvantage for geographically dispersed and decentralized community-based organizations.

Fourth and finally, research has shown some evidence that intragovernmental relations matter for transparency. One variable that is affected by the democratic context is the level of competition and adversity between political actors. Greater competition may result in a greater balance of power between parties and lower levels of party dominance in environmental policy (Ringquist, 1993). In this article, the scope of interparty competition is broadened to include intrastate competition because it has been found to be relevant for local-level transparency (Tan, 2014). For instance, the level of competition between the executive and the controlling branches of government is low in a consensual democracy, because there is a natural need to seek compromise in solving policy issues, resulting in less intrastate rivalry. In the area of transparency, lower intragovernmental competition may result in support for the status quo, causing the government to be less responsive to demands for transparency by outsiders. Work by Gandía and Archidona (2008) for instance, found a positive association 
between political competition and disclosure of information on Spanish city council websites. Since the type of democracy is likely to influence intrastate competition (higher in a majoritarian regime), it is expected that this will affect how administrators deal with environmental transparency.

The literature suggests that the type of democracy shapes how several key stakeholders relate to local government. Unlike the United States, the Dutch consensual system is characterized by less aggressive media, more cooperative industry/business, corporatist interest representation, and more uniform intragovernmental relations. It is expected that this influences how local administrators perceive and act on transparency.

The points made in this theoretical section are summarized in Figure 1. Current research on transparency often focuses only on the arrows on the right side of the figure. In the results section, an empirical map is presented that details the mechanisms on the left side of Figure 1 and how they relate to environmental transparency.

\section{INSTITUTIONAL CONTEXT: COUNTRY INFORMATION}

New Jersey is an ideal case study to examine the impact of the democratic set-up on environmental transparency practices in the United States because of its economic and demographic diversity. Furthermore, New Jersey has a long history of industrial development, with numerous legal frameworks to promote disclosure, and a population of close to 9 million, more than $20 \%$ of whom are registered as foreign-born residents. According to the American Lung Association, in 2014 several metropolitan areas in New Jersey were included in the list of the 25 most polluted cities nationally (www.stateoftheair.org/2014/city-rankings/most-polluted-cities.html).

Air quality regulation is a state-level responsibility in the United States, However, municipalities and counties participate in some aspects of air quality reporting, especially in relation to health and well-being (Laskowski, Morgenstern, \& Blackman, 2005). As a frontrunner

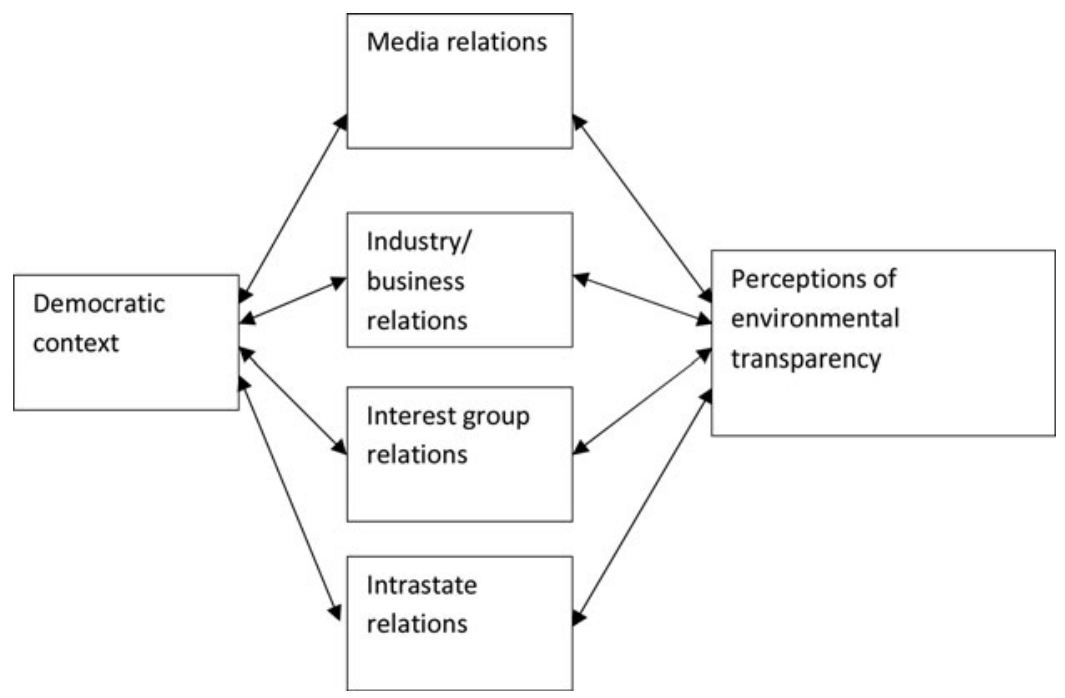

FIGURE 1 Relationships between democratic context and environmental transparency. 
in adopting several environmental regulations, New Jersey preceded the rest of the United States in advancing environmental transparency. For example, the community-driven Right to Know Act was initially passed in New Jersey and was subsequently adopted at the federal level. Other legal tools regulating information disclosure include the Freedom of Information Act and, specific to the state of New Jersey, the 2001 Open Public Records Act, which guarantees access to a wide range of state-level documents, including environment-related ones (Piotrowski, 2011).

\section{OVERVIEW OF THE NETHERLANDS}

With a population of over 16 million and a relatively small geographical area, the Netherlands is one of the most densely populated countries in the world. Because of this and the related emissions, air pollution is a problem in numerous cities in the Netherlands. The European Environment Agency acknowledges this and states that about $90 \%$ of the sulfur dioxide $\left(\mathrm{SO}_{2}\right)$ emissions are caused by industry, energy, and refineries. About $60 \%$ of the nitrogen dioxide $\left(\mathrm{NO}_{2}\right)$, or "nitrogen oxides" $\left(\mathrm{NO}_{\mathrm{x}}\right)$, and carbon monoxide $(\mathrm{CO})$ emissions are caused by transport.

In the Netherlands, the main legal tool for enforcing disclosure is the Wet Openbaarheid van Bestuur, the Dutch counterpart of the U.S. Freedom of Information Act. There is a special and more stringent regime for environmental openness because the Netherlands is a signatory of the multilateral Aarhus Convention, which prescribes proactive disclosure of environmental information. This has been enacted in national environmental regulations. These regulations along with national policy make municipal governments an important hub in reporting and disclosing information.

Municipalities in the Netherlands are relatively autonomous government organizations. Two types of political forces are important in Dutch municipal government: the local council, and a board consisting of the mayor and aldermen (i.e., local political leaders). The local council is the official head of the municipality, while the mayor and aldermen are responsible for its everyday governance. As such they are accountable to the council for their actions.

\section{COMPARING KEY INDICATORS}

Several aspects of Table 1 need to be highlighted. First, a comparison of New Jersey to the Netherlands on some key transparency and pollution indicators is introduced. In 2012, the U.S. PIRG Education Fund evaluated the transparency levels of online government spending data among the 50 states. It rated New Jersey at $\mathrm{C}+$, which indicates that the state offered limited information on spending across cities and counties and tax expenditure data. In another project, conducted by the State Integrity Investigation, which assesses transparency, accountability, and anticorruption mechanisms in the 50 states, New Jersey performed better than other states, with an overall score of B+ (Ginley, 2014). In the Transparency International ranking, the Netherlands was ranked eighth least corrupt in 2013. This means that its overall transparency and corruption levels were slightly better than those of New Jersey. However, the State Integrity ranking demonstrates that in 2014, New Jersey was making significant progress in disclosing and being more accountable, specifically in relation to financial accountability. With regard to 
TABLE 1

Comparative Indicators for New Jersey and the Netherlands

\begin{tabular}{lll}
\hline Indicator & \multicolumn{1}{c}{ New Jersey } & Netherlands \\
\hline Population & 8.865 million (2012) & 16.6 million \\
GDP & $\$ 465.5$ billion (2007) & $\$ 779.36$ billion \\
Transparency indicator & In-State integrity & Corruption Perception Index \\
& Investigation (B+) & $8 / 177$ in 2013 in TI index \\
Environment Sustainability Index & 53.00 (peer group 55.4) & 53.7 (peer group 55.4) \\
& indicator for entire country & \\
Air quality indicators (annual mean & 18 (2008) indicator for & $26(2008)$ \\
\multicolumn{1}{c}{ particulate matter concentration $\left.10 \mu \mathrm{g} / \mathrm{m}^{3}\right)$} & entire country & \\
\hline
\end{tabular}

Sources: World Bank; Yale Center for Environmental Law and Policy (YCELP), Yale University; Center for International Earth Science Information Network (CIESIN), Columbia University; World Economic Forum (WEF); Joint Research Centre (JRC), European Commission, 2005; 2005 Environmental Sustainability Index (ESI), Palisades, NY; NASA Socioeconomic Data and Applications Center (SEDAC), retrieved from http://dx.doi.org/ 10.7927/H40V89R6, accessed September 30, 2014; World Health Organization, retrieved from http://www.theguardian. com/environment/datablog/2011/sep/26/global-air-pollution-who\#data (accessed October 1, 2014).

environmental and air pollution indicators, New Jersey is comparable to the Netherlands. It has a heterogeneous population, and the large number of urban jurisdictions with environmental issues make the state a good comparator for the Netherlands.

\section{METHOD}

\section{Design and Case Selection}

This study employed a qualitative cross-national comparison, but, because of the vast differences between U.S. states with respect to environmental pollution conditions, does not directly compare two nations. Instead, the data source for the United States was one particular state: New Jersey. This facilitated a more in-depth study of transparency than would be possible with a nationwide analysis. The Netherlands and New Jersey were chosen because they are comparable entities due to several factors. They are similar in terms of population size and economic development. Furthermore, they face similar environmental challenges, including high pollution levels (see below for details). Although New Jersey is a state and not an independent country, states in the United States have many nation-like capacities. Similar comparisons between states and countries have been conducted previously (e.g., Nordstrom \& Arens, 1998; Owens, 2008).

\section{Respondent Selection}

In total, 25 employees of government and community-based organizations involved in air pollution issues were interviewed for this project. In the Netherlands, 10 municipalities were selected based on size to represent a broad range of small to very large municipalities (i.e., from 14,000 to 900,000 residents). The 17 respondents were public administrators working for municipal or regional environmental agencies. In the case of New Jersey, a method of snowball sampling was used to select participants. The focus was on urban jurisdictions, including 
several municipalities and urban counties located in the northern part of the state. The selected local jurisdictions in New Jersey had two commonalities, namely, being urban and having a high level of exposure to air pollution. Therefore, the findings of this study may be generalizable to urban local jurisdictions. Representatives of several towns and two counties, with populations ranging from 55,000 to 277,000 and with diverse income levels, were interviewed. The interviews were conducted with municipal, county, or state administrators and with representatives of community-based organizations.

Table 2 provides an anonymized overview of all respondents and their positions.

\section{Interviews and Questions}

The interviews were semistructured; topics and preformulated questions were used to probe initial responses. Each interview lasted from 30 minutes to 1 hour. A Dutch native speaker (one of the authors) conducted the interviews in the Netherlands, while English was used to interview respondents in New Jersey (interviews by both authors). Interviews were conducted both in person and via telephone. In the Netherlands, 16 of the 17 interviews were conducted in person. In New Jersey, six of the eight interviews were conducted in person. All interviews were held privately, with no one other than the interviewer(s) and the interviewee present,

TABLE 2

Interview Respondents in New Jersey and the Netherlands

\begin{tabular}{lll}
\hline \multicolumn{1}{c}{ Affiliation } & Code \\
\hline United States & Small nonprofit & $\mathrm{R} 1$ \\
& Small nonprofit & $\mathrm{R} 2$ \\
& County representative & $\mathrm{R} 3$ \\
Municipal representative & $\mathrm{R} 4$ \\
State representative & $\mathrm{R} 5$ \\
State representative & $\mathrm{R} 6$ \\
Activist & $\mathrm{R} 7$ \\
State representative & $\mathrm{R} 8$ \\
Municipal representative & $\mathrm{R} 9$ \\
Municipal representative & $\mathrm{R} 10$ \\
Municipal representative & $\mathrm{R} 11$ \\
& Municipal representative & $\mathrm{R} 12$ \\
& Municipal representative & $\mathrm{R} 13$ \\
Municipal representative & $\mathrm{R} 14$ \\
Regional representative & $\mathrm{R} 15$ \\
& Regional representative & $\mathrm{R} 16$ \\
Municipal representative & $\mathrm{R} 17$ \\
Municipal representative & $\mathrm{R} 18$ \\
& Municipal representative & $\mathrm{R} 19$ \\
Municipal representative & $\mathrm{R} 20$ \\
Municipal representative & $\mathrm{R} 21$ \\
Municipal representative & $\mathrm{R} 22$ \\
Municipal representative & $\mathrm{R} 23$ \\
Municipal representative & $\mathrm{R} 24$ \\
Municipal representative & $\mathrm{R} 25$ \\
\hline & &
\end{tabular}


TABLE 3

Examples of Interview Questions

\begin{tabular}{ll}
\hline Theoretical determinant & \multicolumn{1}{c}{ Interview question example } \\
\hline Transparency perception & What is the role of information disclosure with regard to air pollution? \\
Media & To what extent are (local) news media paying attention to air pollution? \\
& How? Contacts with journalists? \\
Industry & Do you collaborate with companies on this issue? \\
Interest groups/citizens & Do you collaborate with pressure/interest groups on this issue (transparency)? \\
Intrastate & Is there any involvement of politicians in air pollution information disclosure? \\
& Positive and/or negative? \\
\hline
\end{tabular}

to ensure that respondents would feel free to speak their minds. All respondents agreed to allow the interview to be recorded. The recorded interviews were then transcribed, and the transcripts were used for further analysis (see the next section for details).

The interview questions were based on the theoretical framework presented in Figure 1. Table 3 gives an example question for each theoretical category; a full list of questions is available in the Appendix.

\section{Analysis}

The data were coded by the authors based on the interview transcripts. The Dutch transcripts were coded by the Dutch native speaker; the English ones were coded by both authors. Interview analysis was set up in three phases. First, the transcripts were closely read and coded by drawing on the theoretical categories distinguished in Figure 1: media, industry, interest groups (including individual citizens), and intrastate relations. These theoretical categories were used to apply codes to the data, thus integrating theory with data. Second, both coders independently sought for general patterns among the data in each jurisdiction; these findings are presented in the first two subsections of the results. Third, the general patterns were compared to see the differences and commonalities between the Dutch and New Jersey cases. Respondents are coded in text as R1-R8 for respondents from New Jersey and R9-R25 for Dutch respondents.

\section{RESULTS}

\section{Key Players Influencing Disclosure in New Jersey}

As a complex problem, disclosure of air quality information in New Jersey involves many competing players: community members, nonprofit organizations, industries, public administrators, and local elected officials (R1, R2, R4). Among these, the two most important are the industries and communities affected by pollution. The interviews painted a picture of a rather distrustful relationship between communities and industries. Community representatives noted that environmental reporting is needed to address pollution concerns. At the same time, they acknowledged that the current format of regulations is not sufficient (R1).

The next important factor that shapes environmental transparency is the relationship between communities and government. A typical county or municipality in the United States consists of 
three components: elected officials, legislative council members, and civil servants. In general, the government's position in addressing air quality concerns is perceived with some level of skepticism. Local community-based organizations view themselves as watchdogs who "monitor the government" to ensure that whatever it is doing is good for the public (R2, R7). Interviews with representatives of community organizations reveal differences between their interactions with elected officials and with civil servants:

They are with you or against you. And then you have to play out the organizing card. Can you garner enough political support on the ground level to influence politicians? But it is difficult to do so, because our community is often on the other side, because it is a poor minority community .... Sometimes you can build better ties with champions inside an agency rather than with your own elected officials. (R1)

A more positive picture describes the relationship between community-based organizations and local frontline civil servants. This partnership ensures that they can informally get access to the required information.

You try to build relationship with people in the air division who help you to understand the data. These folks were willing to help you. They will explain the data or give it to you in a format that is more useful for you, as opposed as what is online (facility by facility). They do not have to do that, but if you have a good relationship they may give it to you. (R1)

Nonetheless, local nonprofits felt the need to apply continuous pressure in order to be heard by the government, as is accepted in a majoritarian democratic system (R2, R5). There are several reasons why. Public administrators acknowledge the pressure from diverse groups with distinct interests, but appear to prioritize economic benefits (R4). This trend is particularly prevalent in relatively poor areas, where administrators found environmental regulations to be too expensive.

You know, we would scare the businesses from being able to come to the city or grow in the city if we are overly regulatory on the environmental side. (R4)

Media are expected to be another key player in air pollution information disclosure, yet the respondents in New Jersey had mixed views about the role of media in the process. Nonprofits reported using community-based news agencies to inform the public about environmental events and government decisions on environmental matters (R2).

Yes, we have pretty good relationships with them. When something is very important, we can get them to cover it. (R2)

The respondents, in general, thought that the media in the United States tend to focus on bigger events, or so-called "splash news." They noted that "media did not emphasize in-depth investigations" (R1, R7), although environmental concerns gained significant interest among residents of New Jersey following the 2012 hurricane disaster (R6).

\section{Perceptions of Environmental Transparency in New Jersey}

How do all these players perceive the workings of environmental transparency and disclosure practices? First, almost all the interviewees referred to environmental justice when discussing 
environmental transparency (R1, R2, R3, R7). In official documents, environmental justice is described as "the fair treatment and meaningful involvement of all people, regardless of race, color, national origin, or income with respect to the development, implementation, and enforcement of environmental laws, regulations, and policies" (Executive Order 1289, 1994, p. 8). Environmental justice has been an important element of political discourse since the late 1980s. In 1987, the United Church of Christ's Commission for Racial Justice produced a national report, Toxic Waste and Race (http://d3n8a8pro7vhmx.cloudfront. net/unitedchurchofchrist/legacy_url/13567/toxwrace87.pdf), that provided empirical evidence of the relationship between waste facility locations and demographic variables (Rios, 2000; Rios, Jozwiak, Jorgensen, \& Meyer, 2010). Other studies also found a significant level of exposure to environment hazards among blacks and Hispanics (Bullard, 1992). Consequently, environmental disparity has emerged as an effective tool to galvanize political attention and facilitate disclosure (R7).

There is a real political awareness around environmental justice. Health and environmental problems that people have here are different and worse than in other communities because of wealth and income segregation. (R4)

At the same time, respondents argue that even if the amount of data is increased, this does not necessarily mean that the information will be used. Most of the air quality data in New Jersey are industry-specific, self-reported, and regional (R1, R4, R5, R8). Therefore, the usability of the existing information, particularly by those who are affected, is another dimension of the problem of disclosure.

Their first goal is to meet regulations regarding information disclosure. They only have to do what they have to do, but the law does not ask [them] to disclose information in a way it is understandable to citizens, so most governments won't do that. (R7)

Interviewees agreed that understanding the disclosed environmental information requires specific technical skills or additional financial resources (R2, R5, R8). Both government officials and representatives of community-based organizations thought that the existing information is complex, especially if migrant and low-income communities decide to use it (R5, R6, R8). Furthermore, migrants are new to a system of information disclosure, as "they are coming from countries where that is not a norm" (R7).

As far as obtaining the information we are in general pretty good .... From a potential weakness, I think more the context [is important]: what does it mean to people? A lot of times, the information is a little bit hard to understand for the general public and we tend to throw the technical information out without context and simple explanation on what it means. (R8)

These issues are linked to transparency in several ways. The state of New Jersey does make an effort to publicly disclose information to everyone, but it is used mainly by professionals and environmentalists who are able to identify and understand the data (R2, R7). On the other hand, minority communities, which are more acutely affected by environmental issues and could benefit from obtaining and using information as ammunition, do not have sufficient access, face a language barrier, and/or lack expert knowledge to do so (R1, R3, R7). To address these disclosure problems, the New Jersey Environmental Protection Agency created an Environmental Justice Program to ensure that information is shared with the people who are most impacted (R6). 
In sum, pollution information is a political and contested issue in New Jersey. Lack of trust and competition for government attention are prevalent, as expected under a majoritarian democratic regime, and disclosure is an important tool in this battle. As a result, environmental transparency is perceived as an issue of justice and human rights. It is also perceived as a mechanism to empower. Consequently, the administrator respondents acknowledged that localized data collection on air pollution is important, as is the presentation of the data in a usable format for low-income and immigrant communities.

\section{Key Players Influencing Disclosure in the Netherlands}

Nearly all the civil servants interviewed indicated that they are regularly approached by either the responsible political leader or the council with questions or demands for information about air pollution (R10-R15, R21-R24). This means that attention is focused on the issue by both the local leadership and the council, which ensures periodic and regular attention. This results in transparency in two ways: An alderman who is more interested in the environment may provide information to ensure attention for the issue (e.g., R10). Second, a leader may find transparency an important value (R11, R24). Both of these factors may lead to more openness, such as more advanced websites or strengthening of the information infrastructure.

The local council, holding the political leaders accountable, plays a crucial role in air pollution transparency. Some respondents indicated that political leaders are often scrutinized with regard to air pollution (R12, R15), or at least on a regular basis-for instance, when the annual air pollution report is published (R10, R11, R13, R22, R23). Most respondents admitted that there is a great deal of controversy regarding pollution information. Every year, updated air pollution reports are compiled and published that attract the attention of stakeholders (R16). A great deal of controversy often occurs when pollution measurements yield worse results than the models had predicted, or when local air quality has hardly improved (R9, R10, R13-R15, R22-R24).

Furthermore, the council may also demand enhanced information infrastructure, such as increasing the operational capacity of air pollution stations and/or increased disclosure of air pollution data on websites. If there is enough council pressure, a local alderman may respond by setting up extra operational capacity to measure air pollution or by giving increased political attention to information provision on, for instance, the local government website. Hence, local government transparency is constituted by the interplay between political leaders and the local council.

With regard to external pressures, a few respondents agreed that advocacy groups are influential in forcing improvements in transparency (R10, R22, R23, R24). One respondent highlighted the following:

A few pressure groups here are very critical about current levels of air pollution, and they distrusted our information that was based on calculations. They asked us to actually start measuring air pollution. Because of this lack of trust, our political leader said: "we are going to measure air pollution." Money was made available for this and we now disclose the results of these measurements on a monthly basis. (R24)

Respondents indicated that the news media give little attention to air pollution. If a journalist raises a question, it is often processed through a communications department. In some cities, however, air pollution is a recurring story. One medium-sized city in the Netherlands was 
unable to reduce air pollution because of the busy highways and roads that surround it (e.g., R24). In addition, respondents indicated that there may be questions from journalists concerning infrastructure projects. For instance, when a new road is planned in a populated area, air pollution reports are used to show the detrimental effects on public health and the environment (e.g., R11, R17).

Adversarial relations with industry are very unusual. Since most industrial pollution has been restricted by stringent environmental regulations, pollution comes from more "diffuse" sources, such as car traffic. Nevertheless, information can sometimes be a weapon in projections of the (negative) effects of policy measures on the local economy. For instance, local entrepreneurs might complain about declining patronage if their shops become hard to access by car (e.g., R24).

\section{Perceptions of Environmental Transparency in the Netherlands}

How did the interviewees perceive transparency policy? When mentioning transparency in the interviews, nearly all of the respondents emphasized the importance of being open and transparent, and stated that their organizations were transparent (R9, R11, R14, R16, R18, R19-R21, R23-R25). Some called it "a moral duty" to disclose information (R25), whereas others referred to the Aarhus Convention, which emphasizes the importance of transparency of environmental information (R14, R20, R23).

Others stressed that their organization was transparent because it did not want citizens to get suspicious or mistrusting (R9, R24). For some respondents, transparency was the normal state of government: "you just do it" (R19); "there is no 'secret' information" (R18). In summary, when discussing transparency as a concept, respondents emphasized the importance of this value; they referred to it as a general moral obligation. Those who were administrators indicated that they often struggled with how to implement this "moral obligation" in practice, however, because data have to be disclosed in a complete yet understandable and interpretable format. A large amount of data is gathered and put together in the air pollution reports that most municipalities have to compile and disclose on an annual basis. In these reports, municipalities have to report the current state of air pollution and whether it meets the legal standards set by the European Union.

Nonetheless, determining the degree of pollution is difficult. Measuring air pollution is affected by where the measurement is taken; for instance, one meter closer or farther away from a busy highway makes a huge difference for measurement. Moreover, weather conditions affect the amount of particles in the air. Wind from an unfavorable direction can suddenly increase air pollution in a city. According to respondents, this makes air pollution information difficult to interpret for nonprofessionals.

Because of the contentiousness of measuring, often a combination of modeling and actual measurement is used to estimate air pollution. According to public officials, modeling and calculation is more reliable because it shows long-term trends and validated results. However, citizens often call for actual measurement, as it provides numbers and figures on what the degree of pollution is in a given place at a given time. These measurements show the current day-to-day values of air pollution, which are much more volatile than the long-term trends. One environmental administrator put it as follows: "If you put things on the Internet, you risk that people will give their own interpretations even though their interpretations are not necessarily 
correct" (R14). This notion was expressed by other respondents as well. Fear of misinterpretation causes civil servants to be hesitant to disclose information (R9, R12, R13, R14, R15, R24). Air pollution is thought to be too complex for citizens to understand.

In conclusion, transparency is perceived as a general moral duty of public organizations and, as such, is unquestioned. In practice, disclosing information in a way that is understandable for nonprofessionals is seen as problematic due to the complex nature of air pollution information. Administrators may hesitate to disclose information for paternalistic reasons, fearing that because of its complexity, citizens might interpret it incorrectly.

\section{DISCUSSION}

Although the two jurisdictions studied have similar air pollution problems and are of similar sizes, different democratic conditions and factors bring out different ideas about what transparency is and how it should be implemented. However, remarkable similarities exist in the ways administrators in the Netherlands and New Jersey struggle with the issues of how to disclose information in a complete yet understandable way, and how to best reach the public. The differences and similarities are summarized in Table 4.

The interviews in the United States revealed that disclosure practices are shaped by the battle among elected officials, industries, and local nonprofit organizations. Against this background, nonprofits advance cooperation and partnering with civil servants, which is mostly based on the benevolence of administrators. This further institutionalizes the existing quality of information disclosure because nonprofits with better connections to civil servants can informally access information.

In a consensual context, such as the Netherlands, there are also information-access battles between "insiders" and "outsiders." However, the relations do not seem to be as adversarial as in the United States. The active role of representatives in local councils ensures there is

TABLE 4

Transparency Perceptions and Use in New Jersey and the Netherlands

\begin{tabular}{|c|c|c|}
\hline & New Jersey (majoritarian context) & Netherlands (consensual context) \\
\hline Media & $\begin{array}{l}\text { Mixed views, mostly "splash" news, no } \\
\text { investigations }\end{array}$ & $\begin{array}{l}\text { Moderate to little attention, except in larger } \\
\text { cities }\end{array}$ \\
\hline Industry & Relations are difficult, sometimes adversarial & $\begin{array}{l}\text { No adversarial relations with regard to } \\
\text { transparency }\end{array}$ \\
\hline Interest groups & $\begin{array}{l}\text { Continuous pressure to protect and } \\
\text { empower minorities }\end{array}$ & $\begin{array}{l}\text { Intermittent pressure to prevent } \\
\text { infrastructural projects from being built }\end{array}$ \\
\hline Intrastate & $\begin{array}{l}\text { Frequent conflicts between local government } \\
\text { and external actors (administration vs. } \\
\text { industry, interest groups) }\end{array}$ & $\begin{array}{l}\text { Conflicts about transparency between } \\
\text { local government bodies (council vs. } \\
\text { administration) }\end{array}$ \\
\hline $\begin{array}{l}\text { Perceptions of } \\
\text { transparency } \\
\text { policy }\end{array}$ & $\begin{array}{l}\text { Transparency as a right and a means to } \\
\text { empower }\end{array}$ & $\begin{array}{l}\text { Transparency as a moral obligation and } \\
\text { a means to inform }\end{array}$ \\
\hline $\begin{array}{l}\text { Perceptions of } \\
\text { implementation } \\
\text { dilemmas }\end{array}$ & $\begin{array}{l}\text { Tradeoffs between complexity and } \\
\text { understandability, and between transparency } \\
\text { and secrecy }\end{array}$ & Much the same dilemmas as in New Jersey \\
\hline
\end{tabular}


regular debate between the administrative leadership and opposition political parties, which takes away some of the need for pressure to be exerted by interest groups. Remarkably, and in contrast to New Jersey, adversarial relations seem to occur most often within the local government (alderman vs. council) and less so with outsiders, such as industrial companies. Here the difference in democratic context is relevant, because of the shared and consensual leadership that is prevalent in the Netherlands.

There are differences in the way transparency is debated in the two jurisdictions. In the case of New Jersey, the concern that disadvantaged groups are disproportionally bearing the financial and health burden of environmental problems was one of the factors that led to the enforced reporting of industrial pollution levels. In the case of the Netherlands, consensual politics is better at ensuring political representation of minority interests, and wealth disparities, although present, are much smaller. Administrators formulate transparency in sweeping statements, as a sort of moral obligation for government. Nevertheless, when this moral obligation is put into practice, administrators refuse to disclose certain information because they fear that citizens may misinterpret the complex air pollution information, leading to bad press.

Besides the differences in democratic context, there are variations in the way transparency is perceived by administrators. In the United States, transparency is mainly seen as a legalistic instrument to empower minorities: it is a device in battling for environmental justice and against inequities (cf. Ringquist, 2005). Furthermore, transparency is explicitly perceived by nonprofits and local public administrators in the United States as part of the broader concept of environmental justice. In the Netherlands, transparency is seen as a means to inform the general public: it is an instrument to address pollution in general and to inform citizens. This finding is in line with the expectation that consensual systems lead to balancing out of political power and a more balanced frame. Overall, this finding resonates with recent research comparing communication strategies in the Netherlands and the United States in which Dutch communication advisors tend to have a "principle-based" strategy, whereas their U.S. counterparts tend to opt for a more legalistic approach (Ruijer, 2013).

On the other hand, there were important similarities with regard to the implementation dilemmas that respondents faced. First is the dilemma between disclosure of complex information versus disclosure in an understandable format. Second is the trade-off between transparency and secrecy. Which information should be disclosed and what should be restricted? Dealing with the first dilemma is a daunting task that becomes even more arduous when disclosure is used to empower minority groups, as in the United States. Here information needs to be addressed to a specific public that might not understand it. In the implementation of transparency for empowerment, administrators have to make extra efforts to reach the envisioned audience, let alone to empower them. In the Netherlands, restrictions (besides basic legal requirements) seem to be based on paternalistic motives: "citizens don't understand," so information sometimes is held back altogether.

As is true of any study, the research presented in this article has several limitations. First, it is exploratory in nature. A relatively small sample of respondents was contacted to explore how the democratic environment affects transparency perceptions and use. The sample is focused on only two jurisdictions, which makes it less generalizable for other jurisdictions or states. In addition, the two groups of selected respondents, from New Jersey and the Netherlands, were composed somewhat differently. In practice, it was hard to reach administrators in New Jersey to talk about transparency, which accounts for the limited number of respondents. That said, the 
study does provide a saturated picture of the New Jersey issues, because representatives of community-based organizations were included to supplement the sample.

\section{CONCLUSION}

Despite the near-universal application of transparency in governments in very different democratic contexts, little scholarly attention has been paid to the link between type of democracy and how this this shapes perceptions and use of government transparency. In a majoritarian democratic environment, the environment is a more adversarial and therefore transparency is perceived more as a right and a means of empowerment. In a consensual context, relations are less adversarial and a more institutionalized way to discuss issues of environmental transparency was observed. Transparency here is seen as a moral obligation and a useful tool to inform, but not necessarily empower, citizens. This finding is important, because it indicates that despite the seemingly universal importance attached to government transparency (Hood, 2006; Roberts, 2006), there is no universal "one size fits all" solution.

One crucial point to take from this study is that in a majoritarian situation it is more likely that decision-making will include a relatively narrow set of interests. To compensate, "outsiders," minorities, and other underrepresented groups seek to use transparency as leverage to get a hold on the decision-making process. In a consensual decision-making situation, this occurs less often, as it is less needed. In the search for compromise between political parties and interest groups, a wider range of interests is already represented in consensual decisionmaking. As a result, transparency is much less needed to empower particular underrepresented interests, but it is used obtain information with which to keep the government accountable for its policies in a more general sense.

Remarkably, the type of democratic environment thus matters for how transparency is implemented, but much less for how its implementation is experienced by administrators. Although distinct ideas and uses of transparency were observed, the dilemmas various governments deal with are not very different. In the United States and in the Netherlands, balancing transparency and secrecy, and the question of revealing complete versus understandable information, are central issues in regard to disclosure of air pollution information. The different approaches to how transparency is implemented result in a disparity in accessibility: Employing transparency to empower minority groups, as in the United States, requires that information be understandable to a public that may not be fluent in English.

This exploratory study suggests two directions for more systematic future research on the relation between democracy and transparency. First, in-depth and more qualitative work could include other types of democracies and compare other decision-making cultures, such as nondemocratic, authoritarian regimes. Second, quantitative research could include the type of democracy as an additional variable to measure. For instance, the type of democratic environment could be included as an explanatory variable for transparency. In addition, research could be enriched by introducing various uses of transparency (e.g., informing, empowering) as outcome variables, instead of focusing only on either "more" or "less" transparency.

Overall, this study provides a first exploration of how the type of democratic regime shapes transparency and its implementation. As a result of these differences, government transparency may accomplish completely different goals. It is important for policymakers to understand these nuances in order to tailor disclosure polices to attain a form of transparency that fits their local 
context. More research in this area is needed to fully understand the implications of regime type for how transparency is shaped by its environment.

\section{ACKNOWLEDGMENTS}

A earlier version of this article was presented at the 3rd Global Transparency Research Conference (Paris, 2013) and the Northeast Conference on Public Administration in 2013. The authors would like to thank Ben Worthy and Albert Meijer for their helpful comments. Furthermore, they are particularly indebted to Maurie Cohen for his feedback and opening up his network. This article would not have been possible without the generous travel grant provided by the Fulbright Foundation in the Netherlands.

\section{REFERENCES}

Alrazi, B., de Villiers, C., \& van Staden, C. (2010). The environmental reporting of electric utilities: An international comparison. Paper presented at the 9th CSEAR Australasian Conference, Albury Wodonga, Australia.

Beam, C. (2015, February 6). China tries new tactic to combat air pollution: Transparency. The New Yorker. Retrieved from http://www.newyorker.com/news/news-desk/china-tries-new-tactic-combat-pollution-transparency

Beierle, T. C. (2004). The benefits and costs of disclosing information about risks: What do we know about right-toknow? Risk Analysis, 24(2), 335-346. doi:10.1111/j.0272-4332.2004.00435.x

Binder, S., \& Neumayer, E. (2005). Environmental pressure group strength and air pollution: An empirical analysis. Ecological Economics, 55(4), 527-538. doi:10.1016/j.ecolecon.2004.12.009

Bullard, R. (1992). In our backyards, minority communities get most of the dumps. EPA Journal, 18(1), 11-12. Retrieved from http://nepis.epa.gov/Exe/ZyPDF.cgi/4000083P.PDF?Dockey=4000083P.PDF

Cho, C., Chen, J., \& Roberts, R. (2008). The politics of environmental disclosure regulation in the chemical and petroleum industries: Evidence from the Emergency Planning and Community Right-to-Know Act of 1986. Critical Perspectives on Accounting, 19(4), 450-465. doi:10.1016/j.cpa.2007.03.014

Cucciniello, M., \& Nasi, G. (2014). Transparency for trust in government: How effective is formal transparency? International Journal of Public Administration, 37(13), 911-921. doi:10.1080/01900692.2014.949754

Dahl, R. A. (1947). The science of public administration: Three problems. Public Administration Review, 7(1), 1-11. doi: $10.2307 / 972349$

Executive Order 12898. (1994). Federal Register, 59, No. 32, February 16. Retrieved from http://www.gpo.gov/fdsys/ pkg/FR-1994-02-16/html/94-3685.htm

Furlong, S. R. (1997). Interest group influence on rule making. Administration \& Society, 29(3), 325-347. doi:10.1177/ 009539979702900304

Gandía, J. L., \& Archidona, M. C. (2008). Determinants of Web site information by Spanish city councils. Online Information Review, 32(1), 35-57. doi:10.1108/14684520810865976

Ginley, C. (2014). 50 states and no winners. October 1. Retrieved from http://www.stateintegrity.org/state_integrity_ invesitgation_overview_story

Grimmelikhuijsen, S. G., \& Meijer, A. J. (2014). Effects of transparency on the perceived trustworthiness of a government organization: Evidence from an online experiment. Journal of Public Administration Research and Theory, 24 (1), 137-157. doi:10.1093/jopart/mus048

Grimmelikhuijsen, S. G., \& Welch, E. W. (2012). Developing and testing a theoretical framework for computermediated transparency of local governments. Public Administration Review, 72(4), 562-571. doi:10.1111/j.15406210.2011.02532.x

Grossmann, M. (2012). Interest group influence on US policy change: An assessment based on policy history. Interest Groups and Advocacy, 1, 171-192. doi:10.1057/iga.2012.9

Hallin, D., \& Mancini, P. (2004). Comparing media systems: Three models of media and politics. Cambridge, UK: Cambridge University Press. 
Hood, C. (2006). Beyond exchanging first principles? Some closing comments. In C. Hood \& D. Heald (Eds.), Transparency: The key to better governance? (pp. 211-226). Oxford, UK: Oxford University Press.

Larsen, M., \& Walby, K. (Eds.). (2013). Brokering access. Power, politics, and freedom of information process in Canada. Toronto, Canada: UBC Press.

Laskowski, S., Morgenstern, R., \& Blackman, A. (2005). Environmental decentralization in the United States: Seeking the proper balance between national and state authority. Discussion Paper (RFF DP 05-42). Washington, DC: Resources for the Future. Retrieved from http://www.rff.org/rff/Documents/RFF-DP-05-42.pdf

Licht, J. F., Naurin, D., Esaiasson, P., \& Gilljam, M. (2013). When does transparency generate legitimacy? Experimenting on a context-bound relationship. Governance, 27(1), 111-134. doi:10.1111/gove.12021

Lijphart, A. (1999). Patterns of democracy: Government forms and performance in thirty-six countries. New Haven: Yale University Press.

Lijphart, A., \& Crepaz, M. M. L. (1991). Corporatism and consensus democracy in eighteen countries: Conceptual and empirical linkages. British Journal of Political Science, 21(2), 235-246. doi:10.1017/s0007123400006128

Meijer, A. (2013). Understanding the complex dynamics of transparency. Public Administration Review, 73(3), 429-439. doi:10.1111/puar.12032

Nordstrom, K. F., \& Arens, S. M. (1998). The role of human actions in evolution and management of foredunes in the Netherlands and New Jersey, USA. Journal of Coastal Conservation, 4(2), 169-180. doi:10.1007/bf02806509

Organisation for Economic Co-operation and Development (OECD). (2013). Environment at a Glance 2013. Paris: OECD. Retrieved from http://www.oecd-ilibrary.org/environment/environment-at-a-glance-2013_9789264185715-en

Oswald, K. (1994). Mass media and the transformation of American politics. Marquette Law Review, 77(2), $385-414$.

Owens, K. (2008). Understanding how actors influence policy implementation: A comparative study of wetland restorations in New Jersey, Oregon, The Netherlands and Finland (Doctoral dissertation). University of Twente, Netherlands, Enschede. Retrieved from http://doc.utwente.nl/60135/1/thesis_Owens.pdf

Pasquier, M., \& Villeneuve, J. (2007). Organizational barriers to transparency: A typology and analysis or organizational behaviour tending to prevent or restrict access to information. International Review of Administrative Sciences, 73(1), 147-162. doi:10.1177/0020852307075701

Piotrowski, S. (2011). The operationalization of municipal transparency: Primary administrative functions and intervening factors. Transparência e privacidade, 1(1), 1-31.

Piotrowski, S., \& Van Ryzin, G. (2007). Citizen attitude towards transparency in local government. American Review of Public Administration, 37(3), 306-324.

Relly, J. E., \& Sabharwal, M. (2009). Perceptions of transparency of government policymaking: A cross-national study. Government Information Quarterly, 26(1), 148-157. doi:10.1016/j.giq.2008.04.002

Ringquist, E. (2005). Assessing evidence of environmental inequities: A meta-analysis. Journal of Policy Analysis and Management, 24(2), 223-247. doi:10.1002/pam.20088

Ringquist, E. J. (1993). Environmental protection at the state level: Politics and progress in controlling pollution. Armonk, NY: M.E. Sharpe.

Rios, J. M. (2000). Environmental justice groups: Grass-roots movement or NGO networks? Some policy implications. Review of Policy Research, 17(2), 179-211. doi:10.1111/j.1541-1338.2000.tb00923.x

Rios, J. M., Jozwiak, J., Jorgensen, D., \& Meyer, P. (2010). The changing organizational face of environmental justice: From grassroots to 502c(3) nonprofits. Journal of Public Management and Social Policy, 16(2), 49-66.

Roberts, A. (2006). Blacked out: Government secrecy in an information age. Cambridge, UK: Cambridge University Press.

Roberts, A. S. (2005). Spin control and freedom of information: Lessons for the United Kingdom from Canada. Public Administration, 83(1), 1-23. doi:10.1111/j.0033-3298.2005.00435.x

Royo, S., Yetano, A., and Acerete, B. (2014). E-participation and environmental protection: Are local governments really committed? Public Administration Review, 74(1), 87-98. doi:10.1111/puar.12156

Ruijer, E. (2013). Proactive transparency and government communication in the USA and the Netherlands (Doctoral dissertation). Virginia Commonwealth University, USA. Retrieved from http://scholarscompass.vcu.edu/cgi/ viewcontent.cgi?article $=4232 \&$ context $=$ etd

Tan, Y. (2014). Transparency without democracy: The unexpected effects of China's environmental transparency policy. Governance, 27(1), 37-62. doi:10.1111/gove.12018

Thomas, W. (1928). The child in America: Behavior problems and programs. New York: Alfred A. Knopf. 
U.S. PIRG Education Fund. (2012). Following the money 2012: How the 50 States rate in providing access to government spending data. Retrieved from http://www.uspirg.org/sites/pirg/files/reports/Following\%20the\% 20Money\%20vUS\%20WEB.pdf

van Zyl, A. (2014). How civil society organizations close the gap between transparency and accountability. Governance, 27(2), 347-356. doi:10.1111/gove.12073

Welch, E. W., \& Wong, W. (2001). Global information technology pressure and government accountability: The mediating effect of domestic context on Website openness. Journal of Public Administration Research, and Theory, 11(4), 509-538. doi:10.1093/oxfordjournals.jpart.a003513

\section{APPENDIX: INTERVIEW QUESTIONS}

General

- Can you tell us something about yourself and your work?

Perception of role of information disclosure

- Can you tell me something about the current problems with air pollution in this area?

- What is the role of information disclosure in with regard to air pollution?

- Are you actively providing information to the community in the county/city about this?

- How? E.g. do you disclose information online (i.e., through websites)?

Capacity/expertise

- Does your organization have sufficient expertise and/or capacity to obtain information?

- Does your organization have sufficient expertise and/or capacity to disclose information?

Political/intrastate relations

- Would you qualify this topic to be politically relevant?

- Involvement of politicians in disclosure? Positive and/or negative?

- Involvement of public officials in disclosure? Positive and/or negative?

External influences (media, industry, interest groups, citizens)

- Are external parties in other ways requesting/pressuring for information? What kind of information? What do you do with such requests?

- To what extent are (local) news media paying attention to air pollution? How? Contacts with journalists?

- Do you collaborate with pressure/interest groups on this issue?

- Do you collaborate with companies on this issue?

- Do citizens request/want information about this topic? How?

- Are there parties against disclosing air pollution information? 